\title{
REPORT OF LONG-TERM FOLLOW-UP IN A RANDOMIZED TRIAL COMPARING RADIATION THERAPY AND RADIATION THERAPY PLUS HYPERTHERMIA TO METASTATIC LYMPHNODES IN STAGE IV HEAD AND NECK PATIENTS
}

\author{
RicCardo Valdagni, M.D.*† AND Maurizio Amichetti, M.D. ${ }^{\dagger \ddagger}$ \\ *Divisione di Radioterapia Oncologica, Clinica S. Pio X, Milano; 'Istituto per la Ricerca Scientifica e Tecnologica, Trento; \\ and ${ }^{\ddagger}$ Centro Oncologico, Ospedale S. Chiara, Trento, Italy
}

\begin{abstract}
Purpose: The treatment of inoperable metastatic lymphnodes in patients with head and neck cancer represents a therapeutic challenge. Clinical results using conventional radiation therapy are disappointing; on the other hand, the evaluation of recent innovative radiotherapeutic methods is still pending. The end points of this analysis were focused on long-term local control, on its potential influence on survival, and on late toxicity of a previously reported randomized Phase III study comparing conventionally fractionated radical irradiation alone or combined with local hyperthermia in fixed and inoperable metastatic neck lymphnodes.

Methods and Materials: The medical records of 41 patients (44 nodes) with advanced locoregional Stage IV squamous cell cancer of the head and neck and randomized to treatment in the period 1985-1986 with irradiation alone (22/23 evaluable nodes) or combined with external hyperthermia (18/21 evaluable nodes), were re-evaluated. Results: The statistically significant difference observed in "early" response $(p=0.0164)$ in favor of the combined treatment results in improved 5-year actuarial nodal control $(p=0.015)$. Clinical improvement noted in tumor control positively affects survival, leading to a statistically significant difference in survival at 5 years $(p=0.02)$. With respect to side effects, no clearly enhanced acute or late toxicity has been found; as severe late effects, two patients with bone necroses possibly related to the combined treatment have been observed. Thermal analysis failed to show a significant correlation between heating parameters and the end points of the study.

Conclusion: This report with 5-year follow-up confirms the efficacy and the absence of severe toxicity of the combination of radical radiation and hyperthermia in the treatment of metastatic lymphnodes in Stage IV squamous cell carcinoma of the head and neck.
\end{abstract}

Hyperthermia, Radiation, Local control, Survival, Sequelae.

\section{INTRODUCTION}

In an attempt at improving outcome of fixed and inoperable N3 (46) metastatic squamous cell lymphnodes from the head and neck region, a randomized Phase III trial comparing conventionally fractionated radical irradiation (RT) with or without local external microwave hyperthermia (HT) was conducted in 1985-1986 (50). The end points of that study were the evaluation of response rate at 3 months and acute local toxicity. Although the trial was prematurely closed for ethical reasons, we concluded our report as follows: "The results of this report demonstrate the advantage of adding hyperthermia to conventionally fractionated radical irradiation without an increase in acute irradiation side effects in a group of patients with fixed $\mathrm{N}_{3}$ (TNM-UICC) squamous cell neck nodes from head and neck primary tumors." The medical records of 41 Stage IV head and neck patients (44 nodes) entered onto the trial were reviewed to check late toxicity of the combined modalities, to evaluate if "early" response rates translates into local control, and to analyze the related potential influence on survival.

\section{METHODS AND MATERIALS}

Treatment protocol, patient eligibility, and patient characteristics were described in the first report (50). With the inclusion of four patients previously not analyzed because of limited follow-up, 37 of the 41 accrued patients ( 21 in the control group and 16 in the RT plus HT arm) for a total of 40 nodes (on 44 enrolled, 22 in the RT, and
Reprint requests to: Riccardo Valdagni, Division of Radiation Oncology, Clinica S. Pio X, Via F. Nava 31, 20159 Milan, Italy. Acknowledgements-The authors are grateful to Dr. A. Valentini for the statistical analysis and thank Ms. Tiziana Magnani and Mr. Augusto Micheletti for the skillful technical assistance. The authors wish also acknowledge the clinical contribution of Dr.
G. Pani and Dr. C. Graiff. A special thanks to Malcolm Bagshaw, "magister" in radiotherapy, for accepting R.V. in his Department 10 years ago, honoring him and Paola with the friendship of his family.

Accepted for publication 29 July 1993. 
Table 1. RTOG/EORTC late cutaneous, subcutaneous and osseous radiation morbidity scoring system, and acute cutaneous rcaction scoring systems modified from Fowler et al. (13) and from Miller et al. (29)

\begin{tabular}{|c|c|c|c|}
\hline \multirow{2}{*}{\multicolumn{2}{|c|}{ Skin }} & \multicolumn{2}{|l|}{ RTOG/EORTC late toxicity } \\
\hline & & Subcutaneous tissue & Bone \\
\hline Grade 0 & None & 0 None & 0 None \\
\hline 1 & Slight atrophy & 1 Slight induration (fibrosis) & I Asymptomatic \\
\hline & Pigmentation change & and loss of subcutaneous fat & No growth retardation \\
\hline & Some hair loss & & Reduced bone density \\
\hline 2 & Patchy atrophy & 2 Moderate fibrosis but & 2 Moderate pain or tenderness \\
\hline & Moderate telangiectasia & asymptomatic & Growth retardation \\
\hline & Total hair loss & $\begin{array}{l}\text { Slight field contracture }<10 \% \\
\text { linear reduction }\end{array}$ & Irregular bone sclerosis \\
\hline & $\begin{array}{l}\text { Marked atrophy } \\
\text { Gross telangicctasia }\end{array}$ & $\begin{array}{l}3 \text { Severe induration and loss of } \\
\text { subcutaneous tissue }\end{array}$ & $\begin{array}{l}3 \text { Severe pain or tenderness } \\
\text { Complete arrest bone growth }\end{array}$ \\
\hline & & $\begin{array}{l}\text { Field contracture }>10 \% \text { linear } \\
\text { measurement }\end{array}$ & Dense bone sclerosis \\
\hline & Ulceration & 4 Necrosis & 4 Necrosis/spontaneous fracture \\
\hline 5 & Death & 5 Death & 5 Death \\
\hline 0 & Acute toxicity & & \\
\hline
\end{tabular}

Modified from Fowler et al. (13):

Grade $0=$ Unknown; 1 = No visible reaction; $2=$ Light but definite erythema; $3=$ Moderate erythema; $4=$ Severe erythema (red or pink); $5=$ Dry desquamation ( $<50 \%$ of field); $6=$ Dry desquamation $(>50 \%$ of field); $7=$ Moist desquamation $(<50 \%$ of field); $8=$ Moist desquamation ( $>50 \%$ of field); $9=$ Blister; $10=$ Ulceration.

Modified from Miller et al. (29):

Grade $0=$ None; 1 = Erythema; 2 = Dry desquamation, vesciculation, pruritis; $3=$ Moist desquamation, ulceration, blister; $4=$ Esfoliative dermatitis, necrosis requiring surgical intervention.

18 in RT plus HT arm), are evaluable for this retrospective analysis. Reasons for exclusion of four patients were already reported. Within the group of pre-treatment prognostic factors, nodal dimension remains comparable in the two treatment arms: the average maximum node diameter is $4.94 \mathrm{~cm}$ in RT plus HT versus $4.83 \mathrm{~cm}$ in RT alone group.

The prescribed dose and fractionation was $64-70 \mathrm{~Gy}$ in 2.0-2.5 Gy fractions, five times per week, respectively. Average total nodal dose delivered is also comparable: 68 Gy for the irradiation arm alone and $67.5 \mathrm{~Gy}$ for the combined treatment arm.

Irradiation and hyperthermia treatment technique and scheduling, and thermometry have been already described (50). Briefly, heat was delivered within 20-25 min of irradiation, twice a week with one commercial 280-300 $\mathrm{MHz}$ applicator (MA-150'), to the aim of trying to maintain the "lowest measured" intratumoral temperature at $42.5^{\circ} \mathrm{C}$ for 30 minutes. Thermal parameters analyzed in the first report were the followings: (1) minimum temperature ( $\mathrm{T}$ min) and maximum temperature $(\mathrm{T} \max )$ for each heat session and (2) related Thermal Doses, (3) average $T \max (\overline{\mathrm{Tmax}})$ and $\mathrm{Tmin}(\overline{\mathrm{Tm} i n})$ for all treatments and (4) total maximum and minimum Thermal Dose. The method used to calculate thermal doses has also been previously described $(50)$. In addition, $T_{90}$ and $T_{50}$ as defined by the Duke University group have been calculated $(33,34)$.
The evaluation of acute side effects based on two cutaneous reaction scoring systems modified from Fowler (13) and Miller et al. (29) is reported in Table 1: it includes the already mentioned four patients not analyzed because of limited follow-up. It also describes cutaneous, subcutaneous and bone late toxicity scored according to RTOG/ EORTC recommendations. WHO criteria have been adopted in the evaluation of tumor response (29). Actuarial survival and freedom from local relapse were calculated by the product limit method of Kaplan and Meier (19). Differences between curves were evaluated by the Mantel-Haenszel log-rank test (25). Pearson chi-square was calculated for all the observed frequency tables, with the correction of Yates or Fisher's exact test when necessary.

\section{RESULTS}

The difference in complete response (CR) rate at 3 month evaluation including four patients (four nodes) not previously reported because of limited follow up is still significant ( $p=0.0164)$ with $9 / 22$ CR $(40.9 \pm 10.5 \%)$ in RT arm versus $15 / 18 \mathrm{CR}(83.3 \pm 8.8 \%)$ in RT plus HT arm. Iso-dose Thermal Enhancement Ratio (TER) of 2.04 (C.I. 95\%: 1.18-3.5) can be calculated. Progressive disease (PD) and partial response (PR) were observed in $4 / 22$ $(18.2 \%)$ and $9 / 22(40.9 \%)$ in the conventional arm and $2 / 18(11.1 \%)$ and $1 / 18(5.6 \%)$, respectively, in the com-

' BSD-1000, BSD Medical Corporation, Salt Lake City, UT. 


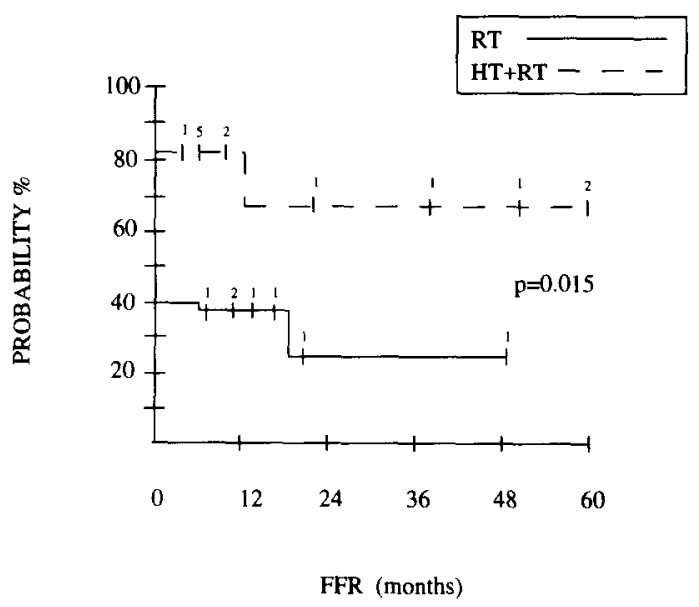

Fig. 1. Kaplan-Meier representation of the probability of freedom from local relapse (FFR) in months.

bined treatment arm. The statistically significant difference noted in favor of the combined modality treatment in "early" response $(36,49)$ evaluation is maintained at 5 years $(p=0.015)$ : as shown in Figure 1, the 5-year actuarial probability of nodal control is $24.2 \%$ ( $\pm 21.1 \%$ ) for the conventional arm versus $68.6 \%( \pm 22.19 \%)$ in the combined arm, leading to a TER value of 2.83 . The frequency of "in-field" recurrences (nodal failure observed in radically treated sites with or without hyperthermia) and "out-field" recurrences (electively irradiated or notirradiated neck regions) are as follows: one "in-field" and 3 "out-field" recurrences occurred in the RT plus HT group versus 2 "in field" and 1 "out-field" nodal failures recorded in irradiated only group. Follow-up of RT patients ranges from 4 to 49 months (median 12 months), while in RT plus HT patients is of 5-80 months (median 18 months). Actuarial survival of the two groups is shown in Figure 2. The 5-year survival favors irradiated and heated patients: $53.3 \%$ ( $\pm 21.03 \%)$ vs. $0 \%$. The difference is statistically significant with a $p$ value of 0.02 . Distant metastases in this stage IV group of patients developed in $19 \%$ of the patients $(12.5 \%$ in RT plus HT and $24 \%$ in RT arm). Metachronous tumors occurred in three pa-

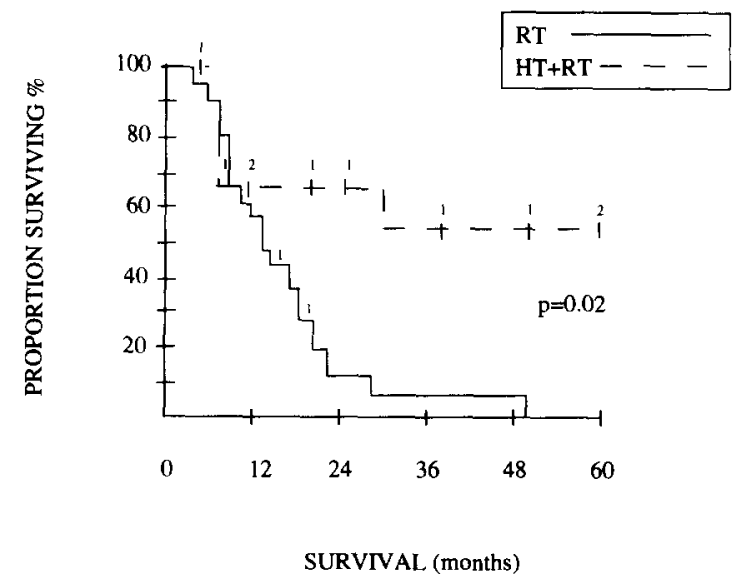

Fig. 2. Kaplan-Meier representation of the probability of survival in months. tients: one in RT plus HT and two in RT arm. Nonneoplastic causes of death were represented by cyrrhosis (one patient), pancreatitis (one patient), COPD-related (onc patient) and cardiovascular disease (one patient) in RT plus HT arm vs. one case of cardiovascular disease in RT alone arm. It must be emphasized that an alcoholic beverage and/or tobacco abuse ( $\geq 1.1$ alcoholic beverage per day, $\geq 20$ cigarettes per day) was known in $69 \%$ and $75 \%$ of cases in the control group and in $81 \%$ and $90 \%$ in the study group, respectively. Thermal parameters analyzed are listed in Table 2 . As previously noted, no apparent correlation were also observed between long-term control or toxicity and thermal parameters. Acute toxicities, including the above mentioned four patients not analyzed in the first report, are listed in Figure 3. Again, no clear evidence of increased acute morbidity was noted. Late sequelae are also shown: as severe toxicity, two grade 4 side effects (bone necrosis) were noted in the combined treatment arm. It must be underlined that both cases occurred with nodes fixed to mandibular bone.

\section{DISCUSSION}

It is well recognized that about one third of patients die of cancer as a consequence of the failure to control local-regional disease $(44,45,47)$. This is in particular the case in patients with head and neck cancer where nodal status (stage, dimension and fixation) represents the single most significant prognostic factor $(5,6,8,28,57)$. Local control of primary tumor and of regional neck disease appear to reduce the incidence of distant metastases and, on the other hand, local recurrence is associated with a higher rate of metastatic dissemination (23). Generally, local regional control tends to improve prognosis in many oncological disease including head and neck tumors (20, $22,44,45,47)$. Standard radiotherapy for squamous cell carcinoma of the head and neck region prescribes $60-70$ Gy in 5 fractions of 1.8-2 Gy per week (26); if metastatic neck lymphnodes of $3.5-6.0 \mathrm{~cm}$ have to be managed, higher doses of at least $75 \mathrm{~Gy}$ (at $2.0 \mathrm{~Gy}$ fractions) or 80 Gy (at 1.8 Gy fractions) are necessary to achieve satisfactory local control rates (30). In spite of total radiation dose delivered, larger nodes exhibit very poor control rates $(12,15,27)$. Innovative radiotherapeutic methods $(7,31)$ have been recently proposed to reduce local and regional failures: pure hyperfractionation $(9,37)$, acceleration ( 21 , $41,53,54)$, continuous hyperfractionated accelerated regimens (42), radiotherapy combined with chemo-radiosensitizers $(1,2,17,18,55)$, non conventional ionizing radiation such as neutron $(16,56)$. Hyperthermia in combination with conventional or hypofractionated irradiation has clearly shown to increase the probability of response with limited and acceptable side effects $(3,35,38$, $48,51)$.

Long-term results of our study, which is reasonably homogeneous for hyperthermia techniques (same applicator, same frequency, etc.), histology (squamous cell carcinoma), nodal status (fixed nodes) and total RT dose 
Table 2. Thermal parameters (see text)

\begin{tabular}{|c|c|c|c|c|}
\hline & & Range & Median & Average \\
\hline $\operatorname{Tmin}\left({ }^{\circ} \mathrm{C}\right)$ & & $37.3-43.9$ & 40.4 & $40.4 \pm 0.2$ \\
\hline $\operatorname{Tmax}\left({ }^{\circ} \mathrm{C}\right)$ & & $39.8-54.2$ & 43.3 & $43.3 \pm 0.2$ \\
\hline $\operatorname{Tmin}\left({ }^{\circ} \mathrm{C}\right)$ & & $38.4-42$ & 40.8 & $40.35 \pm 0.3$ \\
\hline$\overline{T m a x}\left({ }^{\circ} \mathrm{C}\right)$ & & $41-48.28$ & 42.9 & $43.6 \pm 0.5$ \\
\hline $\mathrm{T}_{50}\left({ }^{\circ} \mathrm{C}\right)$ & $41.8 \pm 0.2$ & & & \\
\hline $\mathrm{T}_{90}\left({ }^{\circ} \mathrm{C}\right)$ & $39.8 \pm 0.02$ & & & \\
\hline Min thermal dose $\left(\mathrm{Eq} 42.5^{\circ} \mathrm{C}\right)$ & & $0-95.35$ & 4 & $12.8 \pm 2.1$ \\
\hline Max thermal dose $\left(\mathrm{Eq} 42.5^{\circ} \mathrm{C}\right)$ & & $0.2-293.16$ & 57.3 & $83.84 \pm 9.4$ \\
\hline Total min thermal dose $\left(\mathrm{Eq} 42.5^{\circ} \mathrm{C}\right)$ & & $0-261.92$ & 28.56 & $59.13 \pm 15.65$ \\
\hline Total max thermal dose $\left(\mathrm{Eq} 42.5^{\circ} \mathrm{C}\right)$ & & $9.3-1237.74$ & 224.12 & $326.2 \pm 75.05$ \\
\hline
\end{tabular}

delivered confirm the benefit and the absence of severe treatment-related morbidity of the combination of conventionally fractionated radiation and external microwave hyperthermia. The statistically significant difference in the observed initial 3 month response rate $(p=0.0164)$ is maintained as demonstrated by an actuarial 5-year local control evaluation ( $p=0.015)$. Similar results were observed by Arcangeli et al. (3) in a non-randomized trial showing a complete response rate of $79 \%$ in irradiated and heated nodes, and $42 \%$ in irradiated only nodes. They reported local control rates at 28 months of approximately $58 \%$ and $14 \%$, respectively. Clinical data of a randomized study by Datta et al. (10) confirm these observations, particularly in Stage IV head and neck patients with a $30 \%$ difference in complete responses ( $37 \%$ vs. $7 \%$ ). The same study underlines that disease free survival at 18 months for advanced cases (Stage III-IV) is statistically different
(25\% vs. $8 \%$ ) with a $p$ value of 0.03 . Scott $e t$ al. (43) in paired lesions in the same patient showed a difference of $56 \%(78 \%$ vs. $22 \%)$ in CR at 6 months and of $60 \%$ at 1 year ( $100 \%$ vs. $40 \%)$ follow-up.

The RTOG randomized study (39) using low dose radiation and heat showed no improvement in terms of complete response rates and this was for both smaller and larger than $3 \mathrm{~cm}$ lesions. Technical and clinical limitations of that study have been widely discussed by trial participants (40). In a recent editorial, Oleson, analyzing RTOG study (32), suggests that it may have been a premature (-interinstitutional-) Phase III study in clinical hyperthermia. With the mentioned exception of the RTOG trial, several studies including ours, confirm that hyperthermia combined with irradiation is able to both increase "early" response and decrease local failure rates. Our study, the first reporting results with an extended follow up of 5

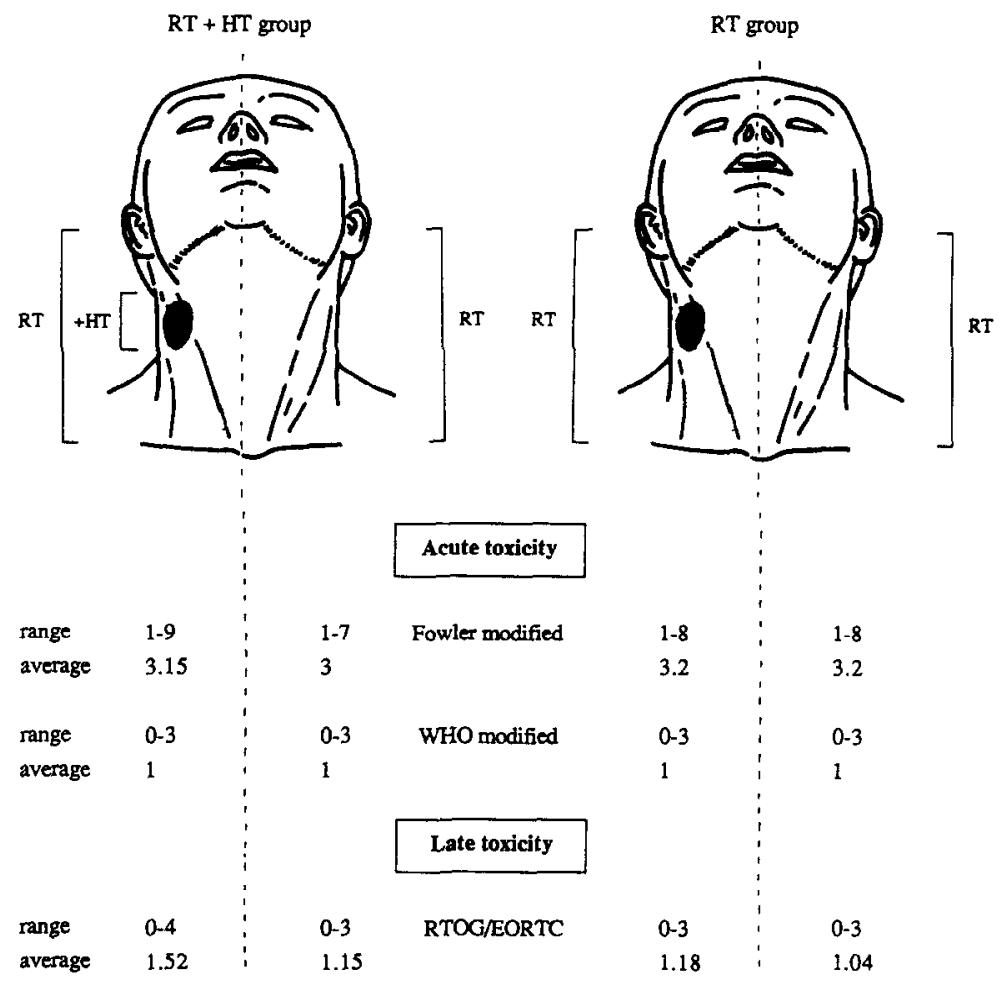

Fig. 3. Acute and late side effects of radiation therapy with or without hyperthermia (see text and Table 1). 
years, also shows that the achievement of nodal control with the addition of hyperthermia to radical radiation can be translated in superior survival rates. Analyzing nodal dimension within the group of pre-treatment parameters (52), we observed similar response rates in the study group with lesions between $3.5 \mathrm{~cm}$ and $3.9 \mathrm{~cm}(4 / 5,80 \%), 4 \mathrm{~cm}$ and $5.9 \mathrm{~cm}(4 / 5,80 \%)$ and $6-7 \mathrm{~cm}(7 / 8,87 \%)$; on the contrary, and confirming the well known concept of nodal dimension as a negative prognostic factor in radiotherapy (4), response rate decreased in the control arm from $50 \%$ $(3 / 6)$, to $44 \%(4 / 9)$, to $28 \%(2 / 7)$, respectively. As far as side effects are concerned, acute toxicity was not significantly enhanced by the combined treatment, as clearly evidentiated in Figure 3; this finding is in agreement with previously published clinical experiences $(3,10,40,43)$. As possible treatment related significant toxicity, we previously reported a case of carotid rupture at 2 month follow-up occurred in the combined treatment arm: it must be underlined that this event, also reported by others (24), was the only case observed in 173 nodes treated in the period 1981-1991 (M. Amichetti, unpublished data, December 1992). Severe side effects were also limited: we recorded two patients with bone necroses in the combined group. It must be noted that this event, in one patient was probably related to a tooth extraction 22 months after the completion of therapy, and in the other patient osteora- dionecrosis occurred in a region of a previous focus of periodontal disease. Such complication has been described in the literature after external beam radiotherapy (14). Nonetheless, the possibility of heat-induced injury to mandibular bone cannot be excluded, as clearly described by Eriksson and Adell for the placement of implants using osseointegration technique (11). Despite the extensive thermal analysis performed, we were unable to find a relation between thermal parameters and response or toxicity; and the sub-trial comparing two or six hyperthermia sessions yielded similar results $(8 / 10,80 \%$, complete response with 6 sessions vs. $7 / 8,87 \%$, with two sessions).

\section{CONCLUSION}

This 5-year analysis on a Phase III randomized trial comparing conventionally fractionated radical radiation with radical radiation plus hyperthermia to metastatic neck nodes in a Stage IV group of patients demonstrates that the combined treatment: (1) Significantly improves actuarial nodal control; (2) Significantly improves 5 -year actuarial survival; and (3) does not increase acute toxicity and does not significantly affect late toxicity. Considering the limited number of patients treated, further randomized trials are needed to support these observations.

\section{REFERENCES}

1. Abitbol, A. A.; Schwade, J. G.; Lewin, A. A.; Sridhar, K.; Brandon, A. H.; Markoe, A. M.; Casiano, R. R.; Houdek. P. V.; Serago, C.; Miller, D. J.; Hush, M. S. Hyperfractionated radiation therapy and concurrent 5 -fluorouracil, cisplatin and mitomycin-C in head and neck carcinoma. Am. J. Clin. Oncol. 15(3):250-255; 1992.

2. Al-Sarraf, M.; Pajak, T. F.; Marcial, V. A.; Mowry, P.; Cooper, J. S.; Stetz, J.; Ensley, J. F.; Vele $z$-Garcia, E. Concurrent radiotherapy and chemotherapy with cisplatin in inoperable squamous cell carcinoma of the head and neck. An RTOG study. Cancer 59:259-265; 1987.

3. Arcangeli, G.: Arcangeli, G. C.; Guerra, A.; Lovisolo, G. A.; Cividalli, A.; Marino, C.; Mauro, F. Tumour response to heat and radiation: prognostic variables in the treatment of ncck nodes metastases from head and neck cancer. Int. J. Hyperther. 3:207-217; 1985.

4. Bataini, J. P.; Bernier, J.; Asselain, B.; Lave, C.; Jaulerry, C.; Brunin, F.; Pontvert, D. Primary radiotherapy of squamous cell carcinoma of the oropharynx and pharyngolarynx: tentative multivariate modelling system to predict the radiocurability of neck nodes. Int. J. Radiat. Oncol. Biol. Phys. 14:635-642; 1988.

5. Bataini, J. P.; Bernier, J.; Jaulerry, C.; Brunin, F.; Pontvert, D. Impact of cervical disease and its definitive radiotherapeutic management on survival: experience in 2013 patients with squamous cell carcinomas of the oropharynx and pharyngolarynx. Laryngoscope 100:716-723; 1990.

6. Bernier, J.; Bataini, J. P. Regional outcome in oropharyngeal and pharyngolaryngeal cancer treated with high dose per fraction radiotherapy. Analysis of neck disease response in 1646 cases. Radiother. Oncol. 6:87-103; 1986.

7. Brady, L. W.; Markoe, A. M.; Micaily, B.; Fisher, S. A.;
Lamm, F. Innovatives techniques in radiation oncology. Cancer 65:610-624; 1990.

8. Cerezo, L.; Millan, I.: Torre, A.; Aragon, G.; Otero, J, Prognostic factors for survival and tumor control in cervical lymph node metastases from head and neck cancer. Cancer 69:1224-1234; 1992.

9. Cox, J. D.; Pajak, T.; Marcial, V. A.; Hanks, G. E.; Mohiuddin, M.; Fuk, K.; Byhardt, R. W.; Rubin, P. Dose-response for local control with hyperfractionated radiation therapy in advanced carcinomas of the upper aerodigestive tracts: Preliminary report of the Radiation Therapy Oncology Group Protocol 83-13. Int. J. Radiat. Oncol. Biol. Phys. 18:515-522; 1990.

10. Datta, N. R.; Bose, A. K.; Kapoor, H. K.; Gupta, S. Head and neck cancers: results of thermoradiotherapy versus radiotherapy. Int. J. Hyperther. 6:479-486; 1990.

11. Eriksson, R. A.; Adell, R. Temperatures during drilling for the placement of implants using the osseointegration technique. J. Oral Maxillofac. Surg. 44:4-7; 1986.

12. Eschwege, F.; Lartigau, E. Radiotherapy and combined chemoradiotherapy in head and neck carcinoma. Curr. Opin. Oncol. 2:573-577; 1990.

13. Fowler, J. F.; Kragt, K.; Ellis, R. E.; Lindop, P. J.; Berry, R. J. The effect of divided doses of $15 \mathrm{MeV}$ electrons on the skin response of mice. Int. J. Radiat. Oncol. Biol. Phys. 9:241-252; 1965.

14. Galler, C.; Epstein, J. B.; Guze, K. A.; Buckles, D.; Stevenson-Moore, P. The development of osteoradionecrosis from sites of periodontal disease activity: report of 3 cases. J. Periodontol. 63:310-316; 1992.

15. Goffinet, D. R.; Fee, W. E.; Goode, R. L. Combined surgery and postoperative irradiation in the treatment of cervical lymphnodes. Arch. Otolaryngol. 110:736-738; 1984. 
16. Griffin, T. W.; Davis, R.; Hendrickson, F. R.; Maor, M. H.; Laramore, G. E. Fast neutron radiation therapy for unresectable squamous cell carcinomas of the head and neck: the results of a randomized RTOG study. Int. J. Radiat. Oncol. Biol. Phys. 10:2217-2221; 1984.

17. Harrison, L. B.; Pfister, D. G.; Fass, D. E.; Armstrong, J. G.; Sessions, R. B.; Shah, J. P.; Spiro, R. H.; Strong, E. W.; Weisen, S.; Bosl, G. J. Concomitant chemotherapyradiation therapy followed by hyperfractionated radiation therapy for advanced unresectable head and neck cancer. Int. J. Radiat. Oncol. Biol. Phys. 21:703-708; 1991.

18. Jassem, J.; Dewit, L.; Keus, R.; Bartelink, K. Concomitant chemotherapy and radiotherapy. In: Snow, G. B., Clark, J. R., eds. Multimodality therapy for head and neck cancer. New York, NY: Theme Medical Publ. Inc.; 1992:126-146.

19. Kaplan, E. L.; Meier, P. Nonparametric estimation from incomplete observations. J. Am. Stat. Assoc. 53:457-481; 1958.

20. Kapp, D. S. Site and disease selection for hyperthermia clinical trials. Int. J. Hyperthermia 2:139-156; 1986.

21. Lamb, D.; Spry, N.; Gray, A.; Johnson, A. D.; Alexander, S. R.; Dally, M. J. Accelerated fractionation radiotherapy for advanced head and neck cancer. Radiother. Oncol. 18: $107-116 ; 1990$.

22. Leibel, S. A.; Ling, C. C.; Kutcher, G. J.; Mohan, R.; CordonCordo, C.; Fuks, Z. The biological basis for conformal threedimensional radiation therapy. Int. J. Radiat. Oncol. Biol. Phys. 21:805-811; 1991.

23. Leibel, S. A.; Scott, C. B.; Mohiuddin, M.; Marcial, V. A.; Coia, L. R.; Davis, L. W.: Fuks, Z. The effect of local-regional control on distant metastatic dissemination in carcinoma of the head and neck: results of an analysis from the RTOG head and neck database. Int. J. Radiat. Oncol. Biol. Phys. 21:549-556; 1991 .

24. Lindholm, C.-E.; Andréasson, L.; Knöös, T.; Landberg, T.; Ljungberg, $O$. Arterial rupture after microwave-induced hyperthermia and radiotherapy. Int. J. Hyperther. 6:499$509 ; 1990$.

25. Mantel, N. Evaluation of survival data and two new rank order statistics arising in its consideration. Cancer Chemother. Rcp. 50:163-170; 1966.

26. Marcial, V. A.; Pajak, T. F.; Kramer, S.; Davis, L. W.; Stetz, J.; Laramore, G. E.; Jacobs, J. R.; Al-Sarraf, M.; Brady, L. W. Radiation therapy oncology group (RTOG) studies in head and neck cancer. Semin. Oncol. 15:39-60; 1988.

27. Mendenhall, W. M.; Million, R. R.; Cassisi, N. J. Squamous cell carcinoma of the head and neck treated with radiation therapy: The role of neck dissection for clinically positive neck nodes. Int. J. Radiat. Oncol. Biol. Phys. 12:733-740; 1986.

28. Mendenhall, W. M.; Parsons, J. T.; Mancuso, A. A.; Stringer, S. P.; Cassisi, N. J.; Million, R. R. Head and neck: Management of the neck. In: Perez, C. A., Brady, L. W., eds. Principles and practice of radiation oncology, 2 nd ed. Philadelphia, PA: Lippincott Co; 1992:790-805.

29. Miller, A. B.; Hoogstraten, B.; Staquet, M.; Winkler, A. Reporting results of cancer treatment. Cancer 47:207-214; 1981.

30. Million, R. R.; Cassisi, N. J. General principles for treatment of cancers of the head and neck: Radiation therapy. In: Million, R. R., Cassisi, N. J., eds. Management of head and neck cancer: A multidisciplinary approach. Philadelphia, PA: Lippincott Co; 1984:77-90.

31. Mittal, B. B. Advanced techniques in radiation therapy for head and neck cancers. Otolaryngol. Clin. North. Am. 24: 1569-1583; 1991.

32. Oleson, J. R. If we can't define the quality, can we assure it? Int. J. Radiat. Oncol. Biol. Phys. 16:879; 1989.
33. Oleson, J. R.; Dewhirst, M. W.; Harrelson, J. M.; Leopold. K. A.; Samulski, T. V.; Tso, C. Y. Tumor temperature distribution predict hyperthermia effect. Int. J. Radiat. Oncol. Biol. Phys. 16:559-570; 1989.

34. Oleson, J. R.; Samulski, T. V.; Leopold, K. A.; Klegg, S. J.; Dewhirst, M. W.; Dodge, R. K.; George, S. C. Sensitivity of hyperthermia trials outcomes to temperature and time: implications for thermal goals of treatments. Int. J. Radiat. Oncol. Biol. Phys. 25:289-297; 1993.

35. Overgaard, J. The current and potential role of hyperthermia in radiotherapy. Int. J. Radiat. Oncol. Biol. Phys. 16:535$549 ; 1989$.

36. Parsons, T. J.; McCarty, P. J.; Rao, T. V.; Mendenhall, W. M.; Rodney, R. M. On the definition of local control. Int. J. Radiat. Oncol. Biol. Phys. 18:705-706; 1990.

37. Parsons, T. J.; Mendenhall, W.; Cassisi, N.; Isaac, J. H.; Million, R. R. Hyperfractionation for head and neck cancer. Int. J. Radiat. Oncol. Biol. Phys. 14:649-658; 1988.

38. Perez, C. A.; Emami, B.; Scott, R. S.; Hornback, N. B.; Bauer, M.; Hederman, M. A.; VonGerichten, D. Irradiation and hyperthermia in treatment of locally advanced and recurrent head and neck tumors. Head and neck cancer: Scientific perspectives in management and strategies for cure. Jacobs, J. R., et al., eds. New York, NY: Elsevicr; 1987: 334-347.

39. Perez, C. A.; Gillespie, B.; Pajak, T.; Hornback, N. B.; Emami, B.; Rubin, P. Quality assurance problems in clinical hyperthermia and their impact on therapeutic outcome: A report by the Radiation Therapy Oncology Group. Int. J. Radiat. Oncol. Biol. Phys. 16:551-558; 1989.

40. Perez, C. A.; Pajak, T.; Emami, B.; Hornback, N. B.; Tupchong, L.; Rubin, P. Randomized phase III study comparing irradiation and hyperthermia with irradiation alone in superficial measurable tumors. Am. J. Clin. Oncol. 14:133$141 ; 1991$.

41. Peters, L. J.; Ang, K. K.; Thames, H. D. Accelerated fractionation in the radiation treatment of head and neck cancer: a critical comparison of different strategies. Acta Oncol. 27: 185-194; 1988.

42. Saunders, M. J.; Dische, S.; Grosch, E. J.; Fermontr, D. C.; Ashford, R. F. U.; Mahcr, E. J.; Makepeace, A. R. Experience with CHART. Int. J. Radiat. Oncol. Biol. Phys. 21: 871-878; 1991.

43. Scott, R. S.; Johnson, R. J. R.; Story, K. V.; Clay, L. Local hyperthermia in combination with definitive radiotherapy: Increased tumor clearance, reduced recurrence rate in extended follow-up. Int. J. Radiat. Oncol. Biol. Phys. 10:2119$2123 ; 1984$

44. Suit, H. D. Local control and patient survival. Int. J. Radiat. Oncol. Biol. Phys. 23:653-660; 1992.

45. Suit, H. D. Potential for improving survival rates for the cancer patient by increasing efficacy of treatment of the primary lesion. Cancer 50:1227-1234; 1982.

46. TNM Atlas. Illustrated guide to the TNM/pTNM-classification of malignant tumors, 2nd ed., Berlin, Heidelberg, New York: Springer-Verlag; 1985:4-47.

47. Tubiana, M. The role of local treatment in the cure of cancer. Eur. J. Cancer 28A, 12:2061-2069; 1992.

48. Valdagni, R., ed. International Consensus Meeting on Hyperthermia. Final report. Int. J. Hyperther. 6:837-877; 1990.

49. Valdagni, R. Response to Parsons. Int. J. Radiat. Oncol. Biol. Phys. 20:1382; 1991.

50. Valdagni, R.; Amichetti, M.; Pani, G. Radical radiation alone versus radical radiation plus microwave hyperthermia for $\mathrm{N}_{3}$ (TNM-UICC) neck nodes: A prospective randomized clinical trial. Int. J. Radiat. Oncol. Biol. Phys. 15:13-24; 1988.

51. Valdagni, R.; Kamata, R. Iyperthermia of head and neck 
tumors. In: Sugahara, T., Saito, M., eds. Hyperthermic oncology. London, New York, Philadelphia: Taylor \& Francis: 1989:434-437.

52. Valdagni, R.; Liu, F. F.; Kapp, D. S. Important prognostic factors influencing outcome of combined radiation and hyperthermia. Int. J. Radiat. Oncol. Biol. Phys. 15:959-972; 1988.

53. Wang, C. C. Local control of oropharyngeal carcinoma after two accelerated hyperfractionation radiation therapy schemes. Int. J. Radiat. Oncol. Biol. Phys. 14:1143-1146; 1988.

54. Wang, C. C.; Blitzer, P. H.; Suit, H. Twice-a-day radiation therapy for cancer of the head and neck. Cancer 55:2100 $2104: 1985$.
55. Wasserman, T. H.; Kligerman, M. Chemical modifiers of radiation effects. In: Perez, C. A., Brady, L. W., eds. Principles and practice of radiation oncology. Philadelphia, PA: Lippincott; 1987:360-376.

56. Wells, G.; Koh, W.; Pelton, J.; Russell, K.; Griffin, B.; Laramore, G.; Griffin, T.; Parker, R.; Peters, L. J.; Davis, L.; Pajak, T. F. Fast neutron teletherapy in advanced epidermoid head and neck cancer. Am. J. Clin. Oncol. 12:295$300 ; 1989$.

57. Zatterstrom, U. K.; Wennerberg, J.; Ewers, S. B.; Willen, R, Attewell, R. Prognostic factors in head and neck cancer: histologic grading, DNA ploidy, and nodal status. Head Neck 13:477-487: 1991 